\title{
ALTERATIONS OF LIPID PROFILE LEVELS IN 7,12-DIMETHYLBENZ(A)ANTHRACENE INDUCED ULCERATIVE COLITIS RAT MODEL
}

\author{
GEETHA P*, LAKSHMAN KUMAR B, INDRA U, PAVITHRA SHEETAL B
}

Department of Biotechnology, Kongunadu Arts and Science College, Coimbatore - 641 029, Tamil Nadu, India. Email: geethapalaniswamy13@gmail.com

Received: 30 December 2016, Revised and Accepted: 16 January 2017

\section{ABSTRACT}

Objective: Ulcerative colitis is a type of inflammatory bowel disease is a chronic gastrointestinal disorder characterized by intestinal inflammation and mucosal tissue damage. We examined the lipid profile levels in murine model of 7,12-dimethylbenz(a)anthracene induced ulcerative colitis

Methods: Serum was separated from whole blood and was used to determine the lipid profile such as total cholesterol (TC), phospholipids (PL), triglycerides (TG), free fatty acids, high-density lipoprotein cholesterol, and low-density lipoprotein cholesterol (LDL-C).

Results: Ulcerative colitis rats exhibit a low level of LDL-C and TC. No significant difference was observed in HDL and TG, and significant difference was observed in PL and free fatty acid serum levels. This communication highlights the lipid profile that occurs in ulcerative colitis.

Conclusion: This study, thus, provides valuable information about the disturbances in the lipids and lipoproteins occur in ulcerative colitis.

Keywords: Ulcerative colitis, 7,12-Dimethylbenz(a)anthracene, Lipoprotein, Low-density lipoprotein, Phospholipids.

(C) 2017 The Authors. Published by Innovare Academic Sciences Pvt Ltd. This is an open access article under the CC BY license (http://creativecommons. org/licenses/by/4. 0/) DOI: http://dx.doi.org/10.22159/ajpcr.2017.v10i4.16858

\section{INTRODUCTION}

Ulcerative colitis is a type of inflammatory bowel disease in which immune dysregulation promotes development of ulcerations in the lining of the colon [1]. It is characterized by recurring episodes of inflammation limited to the mucosal layer of the colon; it invariably involves the rectum and may extend in a proximal and continuous fashion to involve other portions of the colon [2,3]. Main clinical manifestations of ulcerative colitis are abdominal pain, diarrhea, mucous, bloody, and purulent stools $[3,4]$. Although the underlying pathogenesis of the disease was still unknown, the widely accepted hypothesis was that the pathophysiology involves an interaction among immunological, genetic, and environmental factors [4]. The inflammatory bowel disease is becoming more common in Asia, but epidemiologic data are lacking [5]. The highest rates have been reported in India particularly ulcerative colitis, Japan, Middle East, and overall rising trends of inflammatory bowel disease are seen in East Asia [6].

\section{METHODS}

Animal selection

Male Wistar rats (170-200 g) were obtained from the animal house of Mannuthy Veterinary College, Thrissur, Kerala. Animals were maintained under standard conditions $\left(12 \mathrm{hrs}\right.$ light/dark cycle; $25 \pm 3^{\circ} \mathrm{C}$, $45-65 \%$ humidity) and had free access to standard rat feed and water ad libitum. Animals were grouped as control and induced. Induced group was sub-grouped as A, B and induced with 10 , and $20 \mathrm{mg} / \mathrm{kg}$ body weight of 7,12-dimethylbenz(a)anthracene. Animals were sacrificed on $4^{\text {th }}, 8^{\text {th }}, 12^{\text {th }}, 24^{\text {th }}$, and $32^{\text {nd }}$ week from the date of induction by cervical dislocation. Animal studies were performed according to the prescribed guidelines of the committee for the purpose of control and supervision of experiments on animals (659/02/a/CPCSEA), Government of India, India.

Biochemical analysis

Heparinized blood was collected for analysis and serum was prepared from whole blood. The homogenates were centrifuged at $3000 \mathrm{~g}$ for 15 minutes at $4^{\circ} \mathrm{C}$ for cytosolic separation. Serum was separated from whole blood and was used to quantify the lipid profile such as total cholesterol (TC) [7], phospholipids (PL) [8], triglycerides (TG) [9], free fatty acids [10], and high-density lipoprotein (HDL) [11]. Low-density lipoprotein (LDL) was calculated using the following formula:

$\mathrm{LDLC}=\mathrm{TC}-\mathrm{HDL}+(\mathrm{TGL} / 5)$

\section{RESULTS AND DISCUSSION}

Several differences were noted in plasma lipid profile of ulcerative colitis induced rats and control rats (Tables 1 and 2). TC levels were significantly reduced. On $32^{\text {nd }}$ week induced group both $10 \mathrm{mg}$ and $20 \mathrm{mg}$ showed reclined value when compared with control rats $(10 \mathrm{mg}-58.67 \pm 0.65 \mathrm{mg} / \mathrm{dL}$, and $20 \mathrm{mg}-54.57 \pm 0.54 \mathrm{mg} / \mathrm{dL}$ vs.

Table 1: Effect of DMBA on the levels of lipoprotein in serum of control and experimental animals

\begin{tabular}{|c|c|c|}
\hline Groups & HDL-C & LDL-C \\
\hline Group I control & $42.65 \pm 0.65$ & $23.43 \pm 0.21$ \\
\hline \multicolumn{3}{|l|}{ Group II induced } \\
\hline \multicolumn{3}{|l|}{ A. $10 \mathrm{mg}$} \\
\hline $1.4^{\text {th }}$ & $42.44 \pm 0.45^{\mathrm{a} *}$ & $22.14 \pm 0.16^{\mathrm{a} *}$ \\
\hline $2.8^{\text {th }}$ & $42.29 \pm 0.34^{\mathrm{a} *}$ & $19.15 \pm 0.23^{a *}$ \\
\hline $3.16^{\text {th }}$ & $43.14 \pm 0.76^{\mathrm{a} *}$ & $17.21 \pm 0.18^{\mathrm{a} *}$ \\
\hline 4. $24^{\text {th }}$ & $42.13 \pm 0.89^{a *}$ & $15.27 \pm 0.21^{\mathrm{a} *}$ \\
\hline 5. $32^{\text {nd }}$ & $41.34 \pm 0.23^{a *, c *}$ & $13.91 \pm 0.15^{\mathrm{a}, \mathrm{c} *}$ \\
\hline \multicolumn{3}{|l|}{ B. $20 \mathrm{mg}$} \\
\hline 1. $4^{\text {th }}$ & $43.56 \pm 0.87^{a *, b *}$ & $20.51 \pm 0.21^{\mathrm{a} * \mathrm{~b} *}$ \\
\hline $2.8^{\text {th }}$ & $41.65 \pm 0.24^{\mathrm{a} * \mathrm{~b} *}$ & $18.11 \pm 0.17^{\mathrm{a} * \mathrm{~b} *}$ \\
\hline $3.16^{\text {th }}$ & $42.33 \pm 0.77^{\mathrm{a} * \mathrm{~b} *}$ & $14.16 \pm 0.22^{\mathrm{a} * \mathrm{~b} *}$ \\
\hline 4. $24^{\text {th }}$ & $43.09 \pm 1.23^{\mathrm{a} * \mathrm{~b} *}$ & $12.62 \pm 0.18^{\mathrm{a} * \mathrm{~b} *}$ \\
\hline $5.32^{\text {nd }}$ & $42.11 \pm 0.43^{a *, b * d *}$ & $10.19 \pm 0.19^{\mathrm{a} * \mathrm{~b} *, \mathrm{~d} *}$ \\
\hline \multicolumn{3}{|c|}{$\begin{array}{l}\text { Values expressed as mean } \pm \text { SD }(\mathrm{n}=2){ }^{*} \text { Significant at } 5 \%(\mathrm{p}<0.05) \text {. Group } \\
\text { comparison: }{ }^{\mathrm{a}} \text { GII versus GI, }{ }^{\mathrm{b}} \mathrm{GIIB} \text { versus GIIA, }{ }^{\mathrm{c}} \mathrm{GIIA} 5 \text { versus GIIA1, GIIA2, GIIA3 } \\
\text { and GIIA4, }{ }^{\mathrm{d}} \text { GIIB5 versus GIIB1, GIIB2, GIIB3 and GIIB4. HDL-C: High-density } \\
\text { lipoprotein cholesterol, LDL-C: Low-density lipoprotein cholesterol, DMBA: 7,12 } \\
\text { Dimethylbenz(a)anthracene, SD: Standard deviation }\end{array}$} \\
\hline
\end{tabular}


Table 2: Effect of DMBA on the levels of lipids in serum of control and experimental animals

\begin{tabular}{|c|c|c|c|c|}
\hline Groups & TC mg/dL & Phospholipids mg/dL & TG mg/dL & Free fatty acids mg/dL \\
\hline Group I control & $72.67 \pm 3.67$ & $66.33 \pm 1.43$ & $40.54 \pm 1.12$ & $86.55 \pm 2.65$ \\
\hline \multicolumn{5}{|l|}{ Group II induced } \\
\hline \multicolumn{5}{|l|}{ A. $10 \mathrm{mg}$} \\
\hline $1.4^{\text {th }}$ & $70.35 \pm 0.14^{\mathrm{a} *}$ & $73.76 \pm 0.44^{\mathrm{a} *}$ & $41.12 \pm 0.63^{a *}$ & $90.12 \pm 0.35^{\mathrm{a} *}$ \\
\hline $2.8^{\text {th }}$ & $67.31 \pm 0.26^{\mathrm{a} *}$ & $75.44 \pm 0.23^{\mathrm{a} *}$ & $40.22 \pm 0.66^{\mathrm{a} *}$ & $94.35 \pm 0.67^{a *}$ \\
\hline $3.16^{\text {th }}$ & $63.22 \pm 0.43^{a *}$ & $96.43 \pm 0.54^{\mathrm{a} *}$ & $41.01 \pm 0.82^{\mathrm{a} *}$ & $114.51 \pm 0.39^{a *}$ \\
\hline $4.24^{\text {th }}$ & $61.35 \pm 0.73^{a *}$ & $97.26 \pm 0.89^{a *}$ & $41.12 \pm 0.32^{\mathrm{a} *}$ & $114.78 \pm 0.54^{\mathrm{a} *}$ \\
\hline \multicolumn{5}{|l|}{ B. $20 \mathrm{mg}$} \\
\hline $1.4^{\text {th }}$ & $66.32 \pm 0.87^{\mathrm{a} * \mathrm{~b} *}$ & $75.65 \pm 0.45^{\mathrm{a} * \mathrm{~b} *}$ & $40.66 \pm 0.35^{\mathrm{a} * \mathrm{~b} *}$ & $92.45 \pm 0.89^{\mathrm{a} * \mathrm{~b}, \mathrm{w}}$ \\
\hline $2.8^{\text {th }}$ & $64.34 \pm 0.11^{\mathrm{a} * \mathrm{~b} *}$ & $78.34 \pm 0.56^{\mathrm{a} * \mathrm{~b} *}$ & $41.44 \pm 0.89 \mathrm{a} * \mathrm{~b} *$ & $97.23 \pm 0.34^{\mathrm{a} * \mathrm{~b} *}$ \\
\hline $3.16^{\text {th }}$ & $60.23 \pm 0.29^{a *, b *}$ & $100.28 \pm 0.54^{\mathrm{a} * \mathrm{~b}}$ & $41.39 \pm 0.56^{\mathrm{a} * \mathrm{~b} *}$ & $118.09 \pm 0.90^{\mathrm{a} * \mathrm{~b} *}$ \\
\hline $4.24^{\text {th }}$ & $57.87 \pm 0.32^{\mathrm{a} *, \mathrm{~b} *}$ & $101.56 \pm 0.48^{\mathrm{a} * \mathrm{~b} *}$ & $42.01 \pm 0.45^{\mathrm{a} * \mathrm{~b} *}$ & $124.34 \pm 0.48^{\mathrm{a} * \mathrm{~b} *}$ \\
\hline $5.32^{\text {nd }}$ & $54.57 \pm 0.54^{\mathrm{a} *, \mathrm{~b} *, \mathrm{~d} *}$ & $102.45 \pm 0.22^{\mathrm{a} *, \mathrm{~b} *, \mathrm{~d} *}$ & $41.45 \pm 0.73^{\mathrm{a} *, \mathrm{~b} *, \mathrm{~d} *}$ & $126.67 \pm 0.67^{\mathrm{a} * \mathrm{~b} * \mathrm{~d} *}$ \\
\hline
\end{tabular}

Values expressed as mean \pm SD $(\mathrm{n}=2)$. ${ }^{*}$ Significant at $5 \%(\mathrm{p}<0.05)$, Group comparison: ${ }^{\mathrm{a} G I I}$ versus GI, ${ }^{\mathrm{b}} \mathrm{GIIB}$ versus GIIA, ${ }^{\mathrm{G}} \mathrm{GIIA5}$ versus GIIA1, GIIA2, GIIA3 and GIIA4, ${ }^{\mathrm{d}}$ GIIB5 versus GIIB1, GIIB2, GIIB3 and GIIB4, TC: Total cholesterol, TG: Triglycerides, DMBA: 7,12 dimethylbenz(a)anthracene

control - $72.67 \pm 3.67 \mathrm{mg} / \mathrm{dL}$ ). PL, TG, and free fatty acids showed gradual increase in induced group when compare with control rats. From $4^{\text {th }}$ week until $32^{\text {nd }}$ week, the values increased steadily. No significant changes were observed in HDL-C levels in both $10 \mathrm{mg}$ and 20 mg group of induced group. Lowering of LDL-C values was observed in induced group of both doses against control value $(13.91 \pm 0.15$, and $10.19 \pm 0.19$ vs. $23.43 \pm 0.21$ ). The data are expressed as mean \pm standard deviation. Statistical comparison was done at significance level, $\mathrm{p}<0.05$ using SPSS package version 10.0. One-way ANOVA followed by post-hoc analysis of least significant difference was performed.

In another study serum concentration of TC, LDL-C was significantly lowered when compared with healthy controls.

On the other hand, no significant changes were observed in HDL-C levels and TG ulcerative colitis, and healthy subjects [12-15]. PL were significantly increased in another study in ulcerative colitis patients when compared with healthy subjects [16]. In our study, free fatty acids were significantly raised from $4^{\text {th }}$ week until $32^{\text {nd }}$ week in experimental rats when compared with control. In another study, there were a significant raise in fatty acids in inflammatory bowel disease [17-19]. In conclusion, ulcerative colitis rats exhibit lower levels of TC and LDL-C compared to healthy subjects. In addition, no significant changes seen in HDL-C and TG. High level of free fatty acids and PL found when compared with healthy rats. This proves the link between the lipid alteration and ulcerative colitis disease. However, more large-scale studies should be carried to reach the robust conclusions about the lipid alterations reported in ulcerative colitis.

\section{ACKNOWLEDGMENTS}

Authors express our deep sense of gratitude to our Secretary and our Principal of Kongunadu Arts and Science College for their support and motivation.

\section{REFERENCES}

1. Thelen TD, Green RM, Ziegler SF. Acute blockade of IL-25 in a colitis associated colon cancer model leads to increased tumor burden. Sci Rep 2016;6:25643

2. Kornbluth A, Sachar DB; Practice Parameters Committee of the American College of Gastroenterology. Ulcerative colitis practice guidelines in adults (update): American College of Gastroenterology, Practice Parameters Committee. Am J Gastroenterol 2004;99(7):1371-85.

3. Sunyoung L, Michael C, Ilnaz S, Raghav B. Immune-mediated adalimumab-induced thrombocytopenia for the treatment of ulcerative colitis. Int J Pharm Pharm Sci 2015;7(7):456-8.

4. Pengkumsri N, Suwannalert P, Sivamaruthi BS, Wongpoomchai R, Sirisattha S, Tammasakchai A, et al. Molecular, histological and antioxidant evaluation of colitis induced in rats by different concentration of dextran sodium sulphate (5KDA). Int J Pharm Pharm
Sci 2015;7(12):283-7.

5. Huang TY, Chu HC, Lin YL, Lin CK, Hsieh TY, Chang WK, et al. Mangiferin attenuates the symptoms of dextran sulfate sodium-induced colitis inmiceviaNF- $\kappa \mathrm{B}$ and MAPK signalling in activation. Int Immunopharmacol 2009;237:60-82.

6. Krimsky M, Yedgar S, Aptekar L, Schwob O, Goshen G, Gruzman A, et al. Amelioration of TNBS-induced colon inflammation in rats by phospholipase A2 inhibitor. Am J Physiol Gastrointest Liver Physiol 2003;285(3):G586-92.

7. Ng SC, Tang W, Ching JY, Wong M, Chow CM, Hui AJ, et al. Incidence and phenotype of inflammatory bowel disease based on results from the Asia-pacific Crohn's and colitis epidemiology study. Gastroenterology 2013;145(1):158-65.e2.

8. Molodecky NA, Soon IS, Rabi DM, Ghali WA, Ferris M, Chernoff G, et al. Increasing incidence and prevalence of the inflammatory bowel diseases with time, based on systematic review. Gastroenterology 2012;142(1):46-54.e42.

9. Burtis CA, Ashwood ER, editors. Tietz Text book of Clinical Chemistry. $3^{\text {rd }}$ ed. Philadelphia, PA: WB Saunders Company; 1999. p. 809-61.

10. Rouser G, Fkeischer S, Yamamoto A. Two dimensional then layer chromatographic separation of polar lipids and determination of phospholipids by phosphorus analysis of spots. Lipids 1970;5(5):494-6.

11. Rice EW. Triglycerides in serum. In: Roderick MP, editor. Standard Methods in Clinical Chemistry. New York: Academic Press; 1970. p. 215-22.

12. Hron WT, Menahan LA. A sensitive method for the determination of free fatty acids in plasma. J Lipid Res 1981;22(2):377-81.

13. Castelli WP, Doyle JT, Gordon T, Hames CG, Hjortland MC, Hulley SB, et al. HDL cholesterol and other lipids in coronary heart disease. The cooperative lipoprotein phenotyping study. Circulation 1977;55:767-72.

14. Sappati Biyyani RS, Putka BS, Mullen KD. Dyslipidemia and lipoprotein profiles in patients with inflammatory bowel disease. J Clin Lipidol 2010;4(6):478-82.

15. Romanato G, Scarpa M, Angriman I, Faggian D, Ruffolo C, Marin R, et al. Plasma lipids and inflammation in active inflammatory bowel diseases. Aliment Pharmacol Ther 2009;29(3):298-307.

16. Ripollés Piquer B, Nazih H, Bourreille A, Segain JP, Huvelin JM, Galmiche JP, et al. Altered lipid, apolipoprotein, and lipoprotein profiles in inflammatory bowel disease: Consequences on the cholesterol efflux capacity of serum using Fu5AH cell system. Metabolism 2006;55(7):980-8.

17. Koutroubakis IE, Malliaraki N, Vardas E, Ganotakis E, Margioris AN, Manousos ON, et al. Increased levels of lipoprotein (a) in Crohn's disease: A relation to thrombosis? Eur J Gastroenterol Hepatol 2001;13(12):1415-9.

18. Lundin EA, Zhang JX, Lairon D, Tidehag P, Aman P, Adlercreutz H, et al. Effects of meal frequency and high-fibre rye-bread diet on glucose and lipid metabolism and ileal excretion of energy and sterols in ileostomy subjects. Eur J Clin Nutr 2004;58(10):1410-9.

19. Levy E, Rizwan Y, Thibault L, Lepage G, Brunet S, Bouthillier L, et al. Altered lipid profile, lipoprotein composition, and oxidant and antioxidant status in pediatric Crohn disease. Am J Clin Nutr 2000;71(3):807-15. 